\title{
Efektivitas Komunikasi Politik PPP Dalam Menjalin Hubungan Dengan Konstituen Di Kota Medan
}

\author{
Ahmad Tamrin Sikumbang1, Muhammad Husni Ritonga ${ }^{2}$, Aja Syahri ${ }^{3}$ \\ Universitas Islam Negeri Sumatera Utara \\ E-mail: ajasyahri.aja@gmail.com
}

\begin{abstract}
ABSTRAK
Hubungan dengan konstituen merupakan salah satu aspek penting dalam tugas seorang legislator, namun ia penting karena alasan dan dapat memberikan manfaat bagi konstituen, legislator, partai politik dan masyarakat secara keseluruhan. Kontak langsung antara legislator dan warga negara dapat membangun kepercayaan publik kepada legislator dan lembaga legislatif. Penelitian ini bertujuan menganalisis komunikasi politik yang dilakukan PPP dalam menjalin hubungan dengan konstituen di kota Medan. Penelitian ini menggunakan jenis pendekatan deskriptif kualitatif. Waktu penelitian dilakukan selama tiga bulan mulai Desember 2019 hingga Februari 2020 yang berlokasi di kota Medan. Sumber data diperoleh dari hasil observasi dan wawancara dan dokumentasi. Wawancara dengan informan penelitian yaitu terdiri dari anggota DPRD Medan periode 2014-2019, Ketua-Ketua Pimpinan Anak Cabang (PAC), sekretaris Dewan Pimpinan Cabang (DPC) Partai Persatuan Pembangunan (PPP), kemudian juga sumber data dipilih secara purposive sampling dari para narasumber. Teknik analisis data dengan reduksi data dan verifikasi. Teori yang digunakan dalam penelitian ini adalah dengan teori komunikasi interpersonal dalam menjalin hubungan dengan bentuk komunikasi langsung dan tatap muka. Hasil penelitian didapatkan bahwa komunikasi politik yang dilakukan PPP diawali dengan bentuk komunikasi yang terdiri dari identifikasi, legitimasi, partisipasi, penetrasi dan distribusi kemudian dengan tahapan perencanaan komunikasi yaitu mengedepankan nilai-nilai Islam, merangkul tokoh-tokoh agama dan dengan marketing politik.
\end{abstract}

Kata Kunci: Komunikasi politik, PPP, konstituen.

\section{The Effectiveness of PPP Political Communication in Establishing Relations with Constituents in Medan City}

\begin{abstract}
Constituent relations are an important aspect of a legislator's job, but it is important for reasons and can provide benefits to constituents, legislators, political parties, and society as a whole. Direct contact between legislators and citizens can build public trust in legislators and legislatures. This study aims to analyze the political communication carried out by PPP in establishing relationships with constituents in the city of Medan. This research uses a qualitative descriptive approach. When the research was conducted for 3 months from December 2019 to February 2020, located in the city of Medan. Sources of data obtained from observations and interviews and documentation. Interviews with research informants consisted of members of the Medan DPRD for the 2014-2019 period, the Chairperson of the Branch Child Leaders (PAC), the secretary of the PPP Party Branch Leadership Council (DPC), then also the data sources were selected by purposive sampling from the speakers. Data analysis techniques with data reduction and verification. The theory used in this research is the theory of interpersonal communication in establishing relationships with direct and face-to-face forms of communication. The results showed that political communication carried out by PPP began with a form of communication consisting of identification, legitimacy, participation, penetration, and distribution, then with the communication planning stages, namely promoting Islamic values, embracing religious leaders, and with political marketing.
\end{abstract}

Keywords: political communication, PPP, constituents.. 
Korespondensi: Ahmad Tamrin Sikumbang. Jl. William Iskandar Ps. V, Medan Estate, Kec. Percut Sei Tuan, Kabupaten Deli Serdang, Sumatera Utara 20371. No. Hp/WhatsApp. ajasyahri.aja@gmail.com

\section{PENDAHULUAN}

Konstituen merupakan warga negara yang diwakili oleh seorang legislator yang telah terpilih dalam pemilu atau dengan kata lain merupakan anggota atau masyarakat yang mendukung partai saat pemilu. Bagian dari kerja seorang legislator dalam demokrasi adalah melayani konstituen ini dengan mewakili kepentingan mereka dalam lembaga legislatif dan dengan menyediakan hubungan langsung dengan pemerintah.

Keterlibatan yang aktif konstituen memberikan sebuah wajah yang lebih jelas kepada sang legislator, lembaga legislatif, dan partai politiknya. Kendati seorang wakil rakyat terpilih tidak bisa memecahkan semua masalah konstituennya, membantu atau setidaknya mencoba membantu bisa membangun kepercayaan publik kepada legislator dan lembaga legislatif.

Legislator yang membangun komunikasi dua arah dengan konstituen juga dapat memberikan pemahaman yang lebih baik kepada warga negara mengapa mereka membuat keputusan tertentu juga kesulitan-kesulitan yang mereka hadapi, seperti sumber daya keuangan atau yang lain yang tidak memadai. Warga negara yang memiliki kontak langsung dengan seorang wakil terpilih juga lebih cenderung memilih partai legislator tersebut sebagai lembaga yang mereka dukung, sesuatu yang penting khususnya pada masa pemilu.

Komunikasi yang baik harus dibangun dalam membina hubungan dengan konstituen baik secara langsung maupun tidak langsung. Apabila transaksi politik dilakukan atas dasar kesamaan visi dan misi, maka hubungan pemilih dengan yang dipilih akan terikat dalam jangka panjang. Para konstituen bersama legislator pilihannya ikut serta dalam pemilihan umum dengan beragam cara dan strategi untuk mendapatkan suara (Haris, 2005).

Hubungan konstituen merupakan suatu arena di mana ini benar adanya. Lensa yang digunakan setiap aktor untuk melihat representasi dan hubungan dengan konstituen berbeda, namun peran yang mereka mainkan saling melengkapi. Legislator bertanggung jawab untuk mewakili keragaman dalam masyarakat dan untuk membawa keragaman tersebut ke dalam arena pembuatan kebijakan. Perbedaan-perbedaan ini mungkin berakar dan karakteristis, geografis, kesukuan, agama, identifikasi politik, gender atau lainnya namun legislator untuk mewakili mereka di tingkat nasional.

Dalam artikel (Retnaningrum, 2014) Menurut Philips J Vermonte selaku pembicara yang mewakili Center For Strategic and International Studies (CSIS) menilai bahwa ada kendala yang terjadi terkait hubungan antara legislator dengan konstituennya, yaitu:

1. Kesulitan anggota DPR ketika berkomunikasi dengan konstituen hal ini karena adanya pandangan transaksional dari konstituen yang berharap mereka akan diberi imbalan jika mereka bertemu dengan anggota legislatif bukan karena faktor yang saling membutuhkan.

2. Tidak semua anggota DPR mempunyai program konkrit terkait dengan yang dibutuhkan masyarakat saat ini. 
3. Hubungan antara anggota DPR dan konstituen bersifat satu arah. Yaitu ketika anggota DPR memiliki sarana dan mekanisme saat mereka ingin menemui konstituen lewat kegiatan yang diatur oleh orang-orang disekitarnya. Sedangkan, terkadang konstituen sulit menemui anggota DPR karena mereka tidak selalu ada di kantor.

4. Persaingan sesama anggota DPR dari partai yang sama. Akibatnya adalah terkadang mereka saling sibuk hingga lupa untuk lebih memperhatikan kepentingan konstituennya.

5. Kendala geografis, kendala ini juga menjadi salah satu penyebab lebih dari tiga perempat warga tidak pernah dikunjungi wakil rakyatnya.

Partai politik peserta pemilu pada tahun 2014 untuk periode 2014-2019 telah mempersiapkan calon legislatif yang diusung oleh partai-partai yang ada di kota Medan, Partai Persatuan Pembangunan (PPP) mendapatkan jatah 5 kursi di daerah pemilihan (dapil) I, dapil II, dapil III, dapil IV, dan dapil V. Ini dimaknai bahwa Partai Persatuan Pembanguan mampu menghantarkan kadernya ke parlemen dengan mendapatkan kursi di setiap daerah pemilihan (dapil). Dengan terpilihnya 5 legislator di setiap daerah pemilihan tidak menutup kemungkinan memerlukan bantuan dari para konstituen. Dan oleh karena itu sudah pasti hubungan dengan para konstituen telah dilakukan sejak awal, sebelum pemilihan umum.

\section{Menurut Chumaidy (2011: 18) Partai} Persatuan Pembangunan dideklarasikan pada tanggal 5 Januari 1973. Deklarasi pembentukan PPP dilakukan oleh lima deklarator yang merupakan pimpinan empat partai Islam peserta pemilu tahun 1971 dan oleh ketua kelompok persatuan pembangunan (fraksi empat partai Islam di DPR), yaitu:

1. K.H. Idham Chalid, Ketua umum Pengurus besar Nahdlatul Ulama

2. H. Mohammad Syafaat Mintaredja, SH ketua umum Partai Muslimin Indonesia (Parmusi)

3. Haji Anwar Tjokroaminoto, ketua umum PSII

4. Haji Rusli Halil, ketua umum Partai Islam Perti

5. Haji Masykur, ketua kelompok Persatuan Pembangunan di fraksi DPR

Latar belakang berdirinya partai Islam PPP dapat dilihat beberapa dimensi. Dimensi Pertama, dimensi historis. PPP lahir dari sebuah kenyataan adanya cita-cita luhur umat Islam untuk menyatukan diri dalam satu wadah politik Islam sebagai perwujudan dari ukhuwah Islamiyah dan ukhuwah siyasiyah. Kebutuhan adanya wadah yang dapat menghimpun politik umat semakin dirasakan setelah pada pemilu 1971, partai Islam tidak memperoleh suara yang dignifikan (NU 56, Parmusi 29, PSII 10, Perti 2), sedangkan partai Nasionalis Sekuler memperoleh suara yang cukup signifikan (Golkar 231, PNI 20) sedangkan partai Kristen 7 Kursi dan partai Katolik 3 kursi.

Kenyataan lain yang mendorong berdirinya PPP ialah adanya politik pemerintahan yang melakukan restrukturisasi partai politik dengan langkah penyederhanaan orsospol, yang dirumuskan/diamanatkan dalam TAP MPRS No: XXII/MPRS/1966 tentang kepartaian, keormasan dan kekaryaan. 
Dimensi ketiga, yang menjadi latar belakang lahirnya PPP adalah dimensi sosiologis. Sebagai bagian dari umat Islam, PPP tidak bisa dipisahkan dengan gerakkan dakwah dan pembinaan umat yang selama ini kegiatan tersebut dilakukan oleh ormas-ormas Islam yang telah tergabing (fusi politik) dengan PPP. Gerakan dakwah dan pembinaan umat pada hakikatnya adalah merupakan tanggung jawab partai.

Secara politik, Kota Medan juga menjanjikan bagi partai-partai politik untuk meraih suara sebanyak-banyaknya guna menempatkan wakilwakilnya untuk menduduki kursi DPR, DPRD tingkat I, maupun DPRD tingkat II. Oleh karena itu, pemimpin partai politik di tingkat pusat secepat mungkin akan menugaskan para pimpinan dan pengurus wilayahnya di Sumatera Utara, agar berusaha membentuk organisasi partai politiknya di Kota Medan, guna meraih suara dari penduduk Kota Medan yang multi etnis. Apabila ditelusuri secara mendalam bahwa kehadiran partai politik di Kota Medan sama halnya dengan kehadirannya di tiingkat pusat. Sejak Pemilu tahun 1955 sampai Pemilu tahun 2009, partai-partai politik tetap menunjukkan kiprahnya dalam meraup suara penduduk Kota Medan. Seperti halnya PPP, sejak fusi pada tahun 1973, sudah berkiprah di Kota Medan, dan menunjukkan eksistensi organisasi yang tidak kalah pentingnya dengan partai politik lain. Bahkan sampai saat sekarang ini masih bertahan, di tengah gempuran kehadiran partai politik, baik yang memiliki ideologi nasionalisme, maupun ideologi keagamaan, seperti ideologi Islam.
Sejak Orde Baru berkuasa, dan dimulai Pemilu dengan tiga peserta partai politik pada Pemilu 1977, 1982, 1987, 1992, 1997, PPP menduduki peringkat pemenang kedua setelah Golkar, dan menyusul yang terakhir adalah PDI, baik untuk wilayah Sumatera Utara secara keseluruhan, maupun untuk tingkat Kota Medan. Golkar sebagai organisasi peserta pemilu yang di dukung secara penuh oleh pemerintahan Soeharto tentu berusaha untuk memenangkan secara mutlak Pemilu yang dilangsungkan setiap lima tahun sekali. Dan ini terbukti bahwa setiap diadakan Pemilu, Golkar yang menjadi pemenangnya di Kota Medan. Sementara itu, PPP tetap membayang-bayangi kemenangan Golkar dengan jumlah perolehan suara yang bervariasi pada setiap diadakan Pemilu. Kadang-kadang perolehan suara PPP meningkat, kadang-kadang mengalami penurunan, dan ada kalanya tidak berbeda hasilnya dari pemilu sebelumnya. Kemudian, di Kota Medan, ada basisbasis kantong suara PPP yang mutlak memenangkan Pemilu yang diadakan, seperti di Kelurahan Kota Matsum, yakni di sekitar jalan Amaliun, Puri, Utama, dan sekitaran wilayah Mesjid Raya Al-Maksum.

PPP Kota Medan mampu meraih 11 kursi di DPRD Kota Medan. Dua tahun kemudian, tepatnya pada Pemilu tahun 1999, PPP Kota Medan hanya mampu meraih 4 kursi saja. Lima tahun berikutnya, yakni pada Pemilu tahun 2004, PPP Kota Medan tetap meraih 4 kursi saja di DPRD Kota Medan. Dan lebih ironis lagi, pada Pemilu tahun 2009, kursi PPP di DPRD Kota Medan menurun kembali, hanya mampu menempatkan 3 orang wakilnya. Selama 5 tahun, yakni antara hasil pemilu tahun 
1999 sampai pemilu 2004, PPP Kota Medan mengalami stagnasi atau tidak mengalami perubahan signifikan, karena jumlah kursi yang diperoleh PPP Kota Medan tetap, yakni sekitar 4 kursi saja. Kemudian pada lima tahun berikutnya PPP Kota Medan malah kehilangan satu kursi, dan menempatkan wakilnya di DPRD Kota Medan hanya 3 orang. Selain itu, anggota DPRD Kota Medan yang berasal dari PPP Kota Medan, tidak mewakili seluruh dapil (daerah pemilihan) yang ada. Dari data yang ada, hanya 3 sampai 4 dapil saja yang diwakilinya, dari 5 dapil Kota Medan. Ini menunjukkan bahwa sebaran pemilih PPP Kota Medan tidak merata, hanya pada daerah-daerah pemilihan tertentu saja.

Berdasarkan analisis peneliti, menunjukkan bahwa hanya daerah yang basis keagamaan (Islam) yang banyak saja yang mampu dipengaruhi oleh PPP Kota Medan untuk memilih. Sementara bagi pemilih yang sebaran penduduknya merata dari segi agama dan suku, tidak mampu dikuasai oleh $\mathrm{P}$ PP Kota Medan. Contoh sederhana adalah pada dapil Medan 4 (kecamatan Medan Petisah, Medan Barat, Medan Baru dan Medan Helvetia), selama 10 tahun terakhir, PPP Kota Medan tidak mampu menempatkan wakilnya dari dapil ini untuk duduk di DPRD Kota Medan. Kemudian, pada Pemilu tahun 2009, PPP Kota Medan tidak mampu menempatkan wakilnya dari dua dapil, yakni Dapil Medan 3 dan Dapil Medan 4. Kondisi ini tentu menjadi masalah serius yang harus dicari akar permasalahannya oleh pengurus PPP Kota Medan dan anggota DPRD Kota Medan yang mewakili PPP Kota Medan. Terjadinya penurunan drastis perolehan suara dan kursi PPP di DPRD Kota
Medan selama 10 tahun terakhir juga diamini oleh H.M. Yunus Rasyid, SH. M. Hum ketika peneliti melakukan mewawancarainya. Selaku orang yang pernah memimpin organisasi partai politik berbasis Islam ini (PPP) memang mengakui bahwa terjadi stagnasi pada perkembangan dan perolehan suara PPP di Kota Medan. Hal ini menurut beliau banyak dipengaruhi oleh berbagai faktor, baik itu internal PPP sendiri maupun oleh faktor eksternal PPP.

Dukungan masyarakat atau umat Islam terhadap partai yang memakai lambang Islam, seperti PPP yang menggunakan lambang Ka'bah, sangat berpengaruh terhadap eksistensi dan elektabilitas partai tersebut dalam kancah politik nasional maupun daerah. Eksisnya PPP di Kota Medan sebagai pemenang kedua pada pemilu di era Orde Baru tidak bisa dilepaskan dari simbol-simbol atau lambang yang dipergunakan oleh partai ini dalam meraup suara masyarakat, khususnya umat Islam. PPP disimbolkan sebagai partai umat Islam, dan mampu menyuarakan aspirasi umat Islam di DPRD Kota Medan. PPP menjadi pilihan bagi umat Islam di Kota Medan karena dianggap bahwa PPP merupakan partainya orang Islam. Sejak tahun 1977 sampai 1997, di tengah-tengah tekanan dan intimidasi yang dilakukan oleh penguasa Orde Baru setiap menjelang Pemilu melalui lembaga pemenangan partai di tingkat lokal untuk memenangkan Golkar.Tetapi bagi orang-orang Islam yang ada di Kota Medan sebahagian memilih PPP, dari tiga peserta Pemilu (PPP, Golkar, dan PDI). Alasan sederhana dikemukakan oleh masyarakat Kota Medan, karena PPP adalah simbol dari partai politik Islam. Dan wakil-wakil rakyat yang duduk di DPR, DPRD Tingkat I, DPRD 
Tingkat II, maupun kepengurusan PPP mulai dari tingkat pusat sampai ranting, keseluruhan adalah beragama Islam. Tidak ada anggota masyarakat di luar agama Islam yang masuk ke PPP, baik sebagai pengurus maupun wakil rakyat di DPR.

Pemilu tidak mampu menggoyahkan keinginan sebahagian masyarakat Kota Medan untuk memilih PPP. Setelah era reformasi di mulai, yakni pada tahun 1999 sampai sekarang, puluhan partai politik tumbuh bagaikan cendawan di musin hujan. Demikian juga partai-partai yang menyuarakan aspirasi umat Islam tumbuh dan berkembang, berdampingan dengan PPP. Di Kota Medan, tercatat ada Partai Bulan Bintang (PBB), Partai Keadilan Sejahtera (PKS) dan lain-lain. Kondisi ini mempengaruhi dukungan masyarakat atau umat Islam terhadap PPP, karena banyak pilihan bagi umat Islam untuk menyalurkan aspirasi politiknya, tidak terbatas hanya pada satu partai politik semata.

Dari tiga partai politik yang ada, hanya PPP yang jelas-jelas berbasiskan ajaran Islam dan dianggap mampu membela kepentingan umat Islam di masa itu. Tetapi kepada partai-partai yang berasaskan Islam lainnya atau partai nasional yang memperjuangkan aspirasi umat Islam. Kondisi ini nyata-nyata mempengaruhi perolehan suara PPP di Kota Medan. Hal ini sudah terasa sejak pemilu 1999, 2004 sampai 2009, karena mengalami penurunan perolehan suara dan kursi di DPRD Kota Medan.

Fakta di lapangan menunjukkan bahwa ada banyak orang yang berpikiran sama dengan pikiran narasumber yang peneliti wawancarai dalam melihat perkembangan PPP dewasa ini. Oleh karenanya menjadi masalah yang cukup serius bagi kepengurusan PPP Kota Medan untuk mengembalikan dukungan masyarakat, khususnya umat Islam Kota Medan agar mau kembali memilih dan mendukung PPP Kota Medan.

Selain karena lemahnya dukungan yang diberikan oleh masyarakat atau umat Islam, juga didasarkan kepada program yang ditawarkan oleh PPP Kota Medan yang tidak mampu memberikan pencerahan kepada masyarakat atau umat Islam Kota Medan, baik secara langsung maupun tidak langsung. Semasa Orde Baru, bagi sebahagian masyarakat atau umat Islam tidak terlalu peduli terhadap program yang ditawarkan untuk disampaikan. Hal ini dikarenakan sebahagian masyarakat atau umat Islam menaruh harapan yang besar terhadap kehadiran PPP sebagai sarana atau alat memperjuangkan kepentingan umat Islam di DPRD Kota Medan maupun kepada pemerintah yang berkuasa, baik kepada pemerintah pusat, provinsi maupun pemerintahan Kota Medan.

Informasi yang didapatkan oleh sebahagian masyarakat atau umat Islam terhadap PPP, baik dari berbagai media atau dari berbagai diskusi dan perbincangan dengan berbagai kalangan maupun sanak keluarga, semakin memperluas cara pandangan sebahagian masyarakat atau umat Islam untuk memilih atau tidak memilih PPP dalam setiap Pemilu. Kondisi ini ikut mempengaruhi perolehan suara dan kursi PPP di Kota Medan. Program yang ditawarkan baik dalam kegiatan sehari-hari maupun pada saat kampanye tidak mampu menyentuh kepentingan masyarakat, bahkan cenderung hanya bersifat ide atau gagasan semata, sementara masyarakat atau umat Islam 
butuh action atau pelaksanaan yang dapat dirasakan oleh masyarakat atau umat Islam secara langsung.

Partai Persatuan Pembangunan (PPP) dalam melakukan kegiatan pembinaan umat (sosial dan dakwah) mengamanatkan dan mempercayakannya pada ormas-ormas Islam pendukung langsung partai, yaitu NU, MI/Muhamamdiyah, SI dan Perti. Dengan demikian sebagai partai politik, PPP masih tetap bisa membangun jaringan dengan umat dan masyarakat melalui ormas-ormas tersebut, walaupun pada waktu itu ada system politik hegemonic dan floating mass, baik vertical maupun horizontal (Chumaidy, 2011).

\section{METODE PENELITIAN}

Jenis penelitian ini adalah penelitian lapangan (field research) denganmenggunakan jenis pendekatan yang bersifat deskriptif dan kualitatif. Lokasi penelitian di kota Medan dengan waktu penelitian mulai Desember 2019 hingga Februari 2020. Instrumen penelitian adalah peneliti sendiri. Subjek dan objek penelitian terdiri dari para kader PPP yang terdiri dari Ketua Pimpinan Anak Cabang, sekretaris Dewan Pimpinan Cabang (DPC) dan sumber data dipilih secara purposive sampling. Teknik pengumpulan data dengan observasi lapangan, wawancara dan dokumentasi. Analisis data dengan menggunakan model Spradley, dimulai dengan reduksi data dan diakhiri dengan penarikan kesimpulan atau verifikasi. Teknik keabsahan data dilakukan dengan teknik triangulasi, sehingga data yang didapat lebih konsisten dan valid.

\section{HASIL DAN PEMBAHASAN}

Pada masyarakat yang mempunyai hak pilih (memilih dan dipilih) maka tidak dapat dilepaskan dengan bentuk komunikasi politik, mengingat segala hal yang disampaikan dalam pendidikan politik adalah proses penyampaian pesan/ide-ide politik dari komunikator kepada komunikan (target audience). Strategi komunikasi politik yang dipilih akan dapat menentukan tingkat keberhasilan penyerapan pesan politik yang disampaikan. Oleh sebab itu pihak komunikator (baik dari suprastruktur politik maupun infrastruktur politik) harus emahami karakteristik dari target audiensnya sehingga dapat menentukan sarana yang digunakan. Ada beberapa bentuk komunikasi yaitu:

Gambar Bentuk-Bentuk Komunikasi

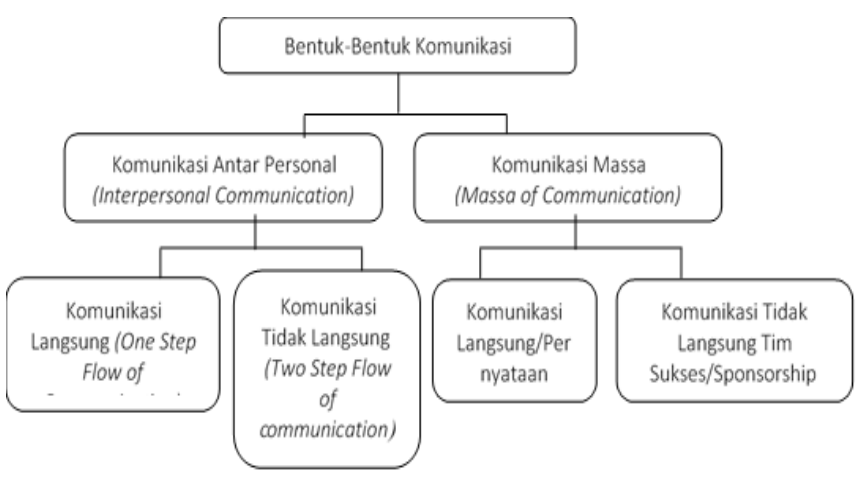

Komunikasi antarpribadi (interpersonal communication) adalah komunikasi antara orangorang secara tatap muka, yang memungkinkan setiap pesertanya menangkap reaksi orang lain secara langsung, baik secara verbal ataupun nonverbal. Bentuk khusus dari komunikasi antarpribadi ini adalah komunikasi diadik (dyadic communication) yang melibatkan hanya dua orang, seperti suami istri, dua sejawat, dua sahabat dekat, guru-murid dan sebagainya. Ciri-ciri komunikasi diadik adalah komunikasi diadik adalah pihakpihak yang berkomunikasi dalam jarak yang dekat, 
pihak-pihak yang berkomunikasi berada dalam jarak yang dekat, pihak-pihak yang berkomunikasi mengirim dan menerima pesan secara simultan dan spontan baik secara verbal maupun nonverbal. Menurut Joseph Devito dalam Wiryanto, Komunikasi antar pribadi merupakan sebuah proses pengiriman dan penerimaan pesan-pesan antara dua orang atau atau di antara sekelompok orang dengan beberapa efek dan beberapa umpan balik seketika (the process of sending and receiving messages between two persons, or among a small group persons, with some effect and some immediate feedback).

Komunikasi antar pribadi pada dasarnya merupakan jalinan hubungan interaktif antara seorang individu dan individu lain di mana lambang-lambang pesan secara efektif digunakan, terutama lambang-lambang bahasa. Penggunaan lambang-lambang bahasa verbal, terutama yang bersifat lisan, di dalam kenyataan kerapkali disertai dengan bahasa isyarat terutama gerak atau bahasa tubuh (body language). Komunikasi antar pribadi pada umumnya dipahami lebih bersifat pribadi (private) dan berlangsung secara tatap muka (face to face). Konsep jalinan hubungan (relationship) sangat penting dalam kajian komunikasi antar pribadi. Jalinan hubungan merupakan seperangkat harapan yang ada pada partisipan yang dengan itu mereka menunjukkan perilaku tertentu di dalam berkomunikasi.

Keberhasilan komunikasi menjadi tanggung jawab para peserta komunikasi. Kedekatan hubungan pihak-pihak yang berkomunikasi akan tercermin pada jenis-jenis pesan atau respons nonverbal mereka. Sebagai komunikasi yang paling lengkap dan paling sempurna, komunikasi antar pribadi berperan penting hingga kapan pun, selama manusia masih mempunyai emosi. Kenyataannya komunikasi tatap muka ini membuat manusia merasa lebih akrab dengan sesamanya.

Dalam penelitian ini menggunakan komunikasi langsung (one step flow of communication) antara legislator dengan konstituen di kota Medan. Model ini menyatakan, saluran-saluran media massa berkomunikasi secara langsung kepada mass audience, dalam ari pesanpesan media mengalir tanpa harus melalui opinion leader. Namun model ini mengakui, pesan komunikasi dimana para penerimanya seluruhnya sama. Efek yang ditimbulkan selalu sama untuk masing-masing penerima.

Komunikasi aliran dua tahap (two step flow model). Konsep komunikasi dua tahap berasal dari Lazarsfeld, Berelson dan Gaudet (1984) yang berdasarkan penelitian bahwa ide-ide sringkali datang dari radio dan surat kabar yang ditangkap oleh pemuka pendapat (opinion leader) dan dari ini mereka berlalu menuju penduduk yang kurang giat. Tahap pertama adalah dari sumbernya yakni komunikator kepada pemuka pendapat yang mengoper informasi, sedang tahap kedua ialah dari mencakup penyebaran pengaruh.

Berdasarkan hasil observasi dan wawancara yang dilakukan peneliti ternyata ditemukan informasi mengenai bentuk komunikasi yang dilakukan oleh partai Persatuan Pembangunan khususnya para Legislator di Kota Medan. Bentuk komunikasi dalam menjalin hubungan dengan konstituen menurut Rahmad Hidayat Matondang yaitu dengan cara "Kita harus mengetahui dulu 
wilayah konstituen kita yang sudah ditetapkan pemerintah buat partai. Sepeti contoh dapil 1 medan meliputi 4 wilayah, lalu kita melihat dan menjalin komunikasi dengan kader politik tiap wilayahnya contoh ketua cabang. sekretaris. Bendahara, anggota maupun ketua kelurahan karena mereka banyak sedikit mengetahui warga wilayah nya. Saat kampanye, kita minta informasi dari yang punya wilayah untuk mengetahui kegiatan warga nya, apa yang sering dilakukan. Kita ambil beberapa kegiatan mereka yang sangat positive. Seperti pengajian (wirid) dan kegiatan olahraga. Kegiatan ini kita ketahui tidak terlepas dari informasi rekan sejawat kita sesama elit politik 1 partai. Dan Saat terpilih, jalin terus dan kita kembangkan komunikasi ke wilayah yang bukan dapil kita karena kalau kita sudah terpilih pasti kita buat dapil yang lain hanya kita tidak melupakan asal kita".

Bentuk komunikasi diatas mengacu pada teori perkembangan lima tahap fungsional oleh Larson (1993). Tahap kegiatan meliputi identifikasi, legitimasi, partisipasi, penetrasi dan distribus (Nimmo, 1993). Di dalam teori ini fokusnya pada tahapan kegiatan kampanye, bukan pada proses pertukaran pesan.

\section{Tahap identifikasi}

Pada tahap ini para calon anggota dewan akan melakukan penciptaan identitas kampanye agar dengan mudah dapat dikenali khalayak. Identitas tersebut dengan penggunaan antara lain: warna, simbol/logo dan slogan. Warna akan memberi arti terhadap suatu objek. Oleh karena itu pada umumnya warna yang dipergunakan oleh para calon anggota legislatif untuk alat peraga kampanye disesuaikan dengan branding masingmasing partai yang diwakilinya. Sebagai contoh warna hijau adalah calon legislatif dari Partai Persatuan Pembangunan (PPP). Warna memang salah satu simbol yang partai yang menarik, mudah diingat dan dipahami oleh masyarakat atau konstituen. Saking melekatnya warna sebagai simbol partai, maka seseorang akan selalu mengaitkan warna yang dipilih atau dipakai seseorang dengan partai tertentu. Begitu besarnya pengaruh penggunaan warna, seorang calon anggota legislatif melakukan "warnaisasi" semua barang-barang atau benda-benda miliknya seperti cat rumah, genteng, pagar, mobil, kendaraan, kemeja, celana, handphone, dan barang-barang lainnya. Selain warna, simbol atau logo juga memegang peran penting dalam penciptaan identitas kampanye agar dengan mudah dapat dikenali khalayak. Dalam hal ini simbol yang sering dipergunakan caleg adalah nomor urut caleg di partai yang diwakilinya dalam sebuah daerah pemilihan (dapil). Sedangkan logo yang dipergunakan seorang caleg adalah berupa logo partai. Hal ini sebagaimana yang dikemukan oleh salah seorang key informan berikut ini yaitu $\mathrm{Hj}$ Hamidah "Warna yang saya pergunakan sebagai identitas dalam alat-alat kampanye mengacu pada warna simbol dari partai yang saya wakili. Hal ini untuk mempermudah calon pemilih atau masyarakat dalam mengenali saya sebagai caleg”.

\section{Tahap Legitimasi}

Tahap legitimasi akan diperoleh ketika seseorang telah masuk dalam daftar calon tetap (DCT) anggota legislatif. Pada tahap legitimasi ini seorang calon legislatif harus berjuang secara 
administratif agar terpenuhi syarat-syaratnya sebagai seorang caleg sehingga dapat masuk dalam DCT. Legitimasi mereka bisa efektif digunakan dan dipertahankan sejauh mereka dianggap kapabel dan tidak menyalahgunakan jabatan yang nantinya akan diraihnya.

\section{Tahap Partisipasi}

Partisipasi adalah keikutsertaan para caleg secara nyata atau simbolik. Partisipasi nyata ditunjukkan oleh keterlibatan orang-orang dalam menyebarkan pamflet, kartu nama, brosur atau poster, menghadiri kegiatankegiatan yang diselenggarakan sebuah organisasi sosial kemasyarakatan atau lembaga swadaya masyarakat. Sedangkan partisipasi simbolik adalah dengan pemberian bantuan atau sumbangan kepada partai yang diwakilinya maupun masyarakat.

\section{Tahap Penetrasi}

Pada tahap ini seorang caleg telah hadir dan mendapat tempat di hati masyarakat atau konstituen. Seorang caleg telah menguasai sekian persen dari konstituen yang ada. Seorang juru kampanye telah berhasil menarik simpati masyarakat dan meyakinkan mereka bahwa ia adalah caleg terbaik dari sekian caleg yang ada. Sebuah kampanye yang ditujukan untuk menentang kebijakan pemerintah mendapat liputan media massa secara luas dan mendapat tanggapan serius pemerintah dengan membuka dialog untuk mencari jalan keluar terbaik.

\section{Tahap Distribusi}

Tahap ini merupakan tahap pembuktian para caleg. Pada tahap ini tujuan kampanye politik telah tercapai. Caleg telah mendapatkan kekuasaan atau jabatan yang mereka cari dengan keluar sebagai pemenang atau terpilih untuk menjadi wakil rakyat. Selanjutnya, caleg harus mampu membuktikan janji-janjinya pada saat melakukan kampanye politik dahulu. Dan masyarakat akan terus menilai dan mengawasi gerak-gerik serta perjuangan para caleg.

Bentuk komunikasi atau Kampanye Politik agar dapat berjalan baik sesuai dan efektif. Maka perlu dilakukan perencanaan komunikasi yang cermat. Setidaknya ada enam langkah yang bisa ditempuh dalam perencanaan komunikasi untuk kampanye, yaitu Analisis khalayak (audiens) dan kebutuhannya, Penetapan sasaran atau tujuan komunikasi, Rancangan strategi yang mencakup; komunikator, saluran (media), pesan dan penerima, Penetapan tujuan pengelolaan (management objectives), Implementasi perencanaan yang mencakup; besarnya dana, sumber dana dan waktu dan Evaluasi yang mencakup, evaluasi formatif dan evaluasi summatif.

Selain perencanaan komunikasi, langkahlangkah yang akan dilakukan untuk sebuah kampanye adalah, sebagai berikut.

- Penemuan dan penetapan masalah

- Menetapkan tujuan yang ingin dicapai

- Penetapan strategi (Penetapan juru kampanye (komunikator), Penetapan target sasaran dan analisis kebutuhan khalayak, Menyusun pesanpesan kampanye, Pemilihan media dan saluran komunikasi, Produksi media, Pretesting Communication Material).

- Penyebarluasan pesan melalui media komunikasi

- Pengaruh (effect) kampanye

- Mobilisasi kelompok berpengaruh 
- Penyusunan anggaran belanja

- Penyusunan jadwal kegiatan kampanye (time schedule)

- Tim kerja

- Evaluasi (post testing)

Perencanaan komunikasi yang telah dirancang di aplikasikan dalam bentuk komunikasi sosialisasi/silaturrahmi langsung dengan konstituen sesuai dengan pendapat Adam Malik Rambe ia mengatakan bahwa "Komunikasi politik yang dibangun elit politik yang konstituen ataupun bukan konstituen. Dengan masyarakat nya kita menjalin silaturahmi secara kekeluargaan dengan membawa kader internal wilayah tersebut. Membawa ketua. Sekertaris, Bendahara dan Anggota partai".

Silaturahmi adalah merupakan satu dari akhlak seorang muslim. Allah Ta'ala telah menyeru hambaNya berkaitan dengan menyambung tali silaturahmi di dalam kitab-Nya yang mulia. Firman Allah swt: Artinya: "Hai sekalian manusia, bertakwalah kepada Tuhan-mu yang telah menciptakan kamu dari seorang diri, dan dari padanya. Allah menciptakan isterinya; dan dari pada keduanya Allah memperkembang biakkan laki-laki dan perempuan yang banyak. dan bertakwalah kepada Allah yang dengan (mempergunakan) nama-Nya kamu saling meminta satu sama lain, dan (peliharalah) hubungan silaturrahim. Sesungguhnya Allah selalu menjaga dan mengawasi kamu." Manfaat yang diperoleh melalui silaturami tersebut dalam konteks politik para calon anggota legislatif incumbent telah banyak memanfaatkan peluang tersebut dalam rangka pencitraan diri maupun penggalangan suara menghadapi pemilu 2019.

(Surbakti, 1999: 116) Selain silaturrahmi dilakukan oleh legislator, sosialisasi politik juga diperlukan. Sosialisasi politik ialah proses pembentukan sikap dan orientasi politik para anggota masyarakat, sehingga mereka memperoleh sikap dan orientasi terhadap kehidupan politik yang berlangsung dalam masyarakat. Karena itu, metode penyampaian pesan sosialisasi politik dibagi dua yaitu:

1. Pendidikan politik, yaitu suatu suatu proses dialogis antara pemberi dengan penerima pesan. Dengan cara ini dikenal dan dipelajari nilai-nilai, norma-norma, dan simbol-simbol politik.

2. Indoktrinasi politik, yaitu proses sepihak ketika penguasa memobilisasi dan memanipulasi warga masyarakat untuk menerima nilai, normal, symbol yang dianggap penguasa baik, dengan cara pengarahan dan latihan yang sangat disiplin.

Menurut Michael Rush dan Philip Althoff (1997: 30) Sosialisasi politik adalah proses, oleh pengaruh mana seorang individu bisa mengenali system politik kemudian menentukan sifat persepsi-persepsinya mengenai politik, serta reaksi-reaksinya terhadap gejala-gejala politik. Pentingnya sosialisasi politik yaitu:

- Sosialisasi merupakan proses hasil belajar dari pengalaman.

- Memberikan indikasi umum hasil belajar tingkah laku individu, yang berkenaan dengan pengetahuan atau informasi, motif-motif, nilainilai dan sikap-sikap. 
- Sosialisasi tidak perlu dibatasi pada usia anak-anak dan remaja saja, tetapi harus berkelanjutan sepanjang hidup sebagai politisi.

Sosialisasi yang telah dilakukan dalam menjalin hubungan lebih dekat dengan masyarakat sesuai pendapat $\mathrm{Hj}$ Hamidah yang mengatakan bahwa "sosialisasi atau kedekatan yang dibangun dengan konstituen dapat dilakukan sebelum kampanye guna memperkenalkan partai dan memperkenalkan calon legislator, saat kampanye sosialisasi harus lebih lancar dan baik dan jangan lupa setelah terpilih komunikasi dengan konstituen harus tetap dijaga. Kalau bisa dibuat jadwal rutin untuk bertemu masyarakat guna mendengarkan keluh kesahnya".

Strategi Pemenangan Pemilu yaitu:

- Mempertahankan basis kontituen partai di seluruh daerah pemilihan.

- Memperluas dukungan masyarakat dan memperkuat jaringan konstituen.

- Meningkatkan peran dan fungsi struktur partai dari Dewan Pimpinan Pusat (DPP), Dewan Pimpinan Wilayah (DPW), Dewan Pimpinan Cabang (DPC), Pimpinan Anak Cabang (PAC) dan Pimpinan Ranting Partai Persatuan Pembangunan (PPP).

- Membangun citra partai yang modern dan dinamis, tanggap terhadap perubahan masyarakat, serta memiliki visi dan program perjuangan sesuai dengan kepentingan dalam Muslim (2012: 199 ).

Setelah Kampanye

Komunikasi politik Partai Persatuan Pembangunan (PPP) mengedepankan nilai-nilai keIslaman, hal ini merupakan pendapat informan Syafaruddin S. Ag yang mengatakan bahwa "Islam sebagai asas partai, asas Islam yang dimaksud merupakan sumber motivasi, inspirasi dan sumber nilai dalam kehidupan kemasyarakatan. Nilai-nilai keIslaman yang melandasi bangunan kehiduapan kemsyarakatan berbangsa dan bernegara pada gilirannya akan melahirkan bangsa yang santun, beradab, ramah, penuh toleran dan mengedepankan kebersamaan".

Hubungan yang dibangun legislator dengan konstituen melalui komunikasi politik merupakan hubungan yang sangat penting dan tidak bisa dilupakan begitu saja karena sebelum pemilu, saat pemilu dan pasca pemilu legislator dengan konstituen tidak dapat dipisahkan. Legislator dianggap sebagai penyambung lidah rakyat, sebagai partai politik PPP telah mengikuti pemilihan umum sebagai salah satu kegiatan politik untuk mencari atau mendapatkan mandat dari rakyat untuk memimpin bangsa, baik melalui lembaga eksekutif khususnya lembaga legislatif.

PPP telah mendapat kepercayaan rakyat dengan memperoleh suara terbesar kedua pada masa orde baru dan terbesar ketiga pada masa reformasi. Namun PPP pada pemilu 2009 sampai pemilu 2019 mengalami penurunan. Meski demikian dengan pencapaian yang besar PPP tetap dipercaya oleh rakyat sebagai salah satu partai politik yang diharapkan dapat menyalurkan dan memperjuangkan aspirasinya secara optimal. Kepercayaan rakyat bisa dikarenakan program dan kinerja partai, bisa karena identitas dan jati diri partai dan kemungkinan juga karena kepemimpinan dan calon-calon legislatif yang ditampilkan oleh PPP. 
Komunikasi politik Partai Persatuan Pembangunan (PPP) mengedepankan nilai-nilai keIslaman, hal ini merupakan pendapat informan Syafaruddin S. Ag yang mengatakan bahwa "Islam sebagai asas partai, asas Islam yang dimaksud merupakan sumber motivasi, inspirasi dan sumber nilai dalam kehidupan kemasyarakatan. Nilai-nilai keIslaman yang melandasi bangunan kehiduapan kemsyarakatan berbangsa dan bernegara pada gilirannya akan melahirkan bangsa yang santun, beradab, ramah, penuh toleran dan mengedepankan kebersamaan".

Hubungan yang dibangun legislator dengan konstituen melalui komunikasi politik merupakan hubungan yang sangat penting dan tidak bisa dilupakan begitu saja karena sebelum pemilu, saat pemilu dan pasca pemilu legislator dengan konstituen tidak dapat dipisahkan. Legislator dianggap sebagai penyambung lidah rakyat, sebagai partai politik PPP telah mengikuti pemilihan umum sebagai salah satu kegiatan politik untuk mencari atau mendapatkan mandat dari rakyat untuk memimpin bangsa, baik melalui lembaga eksekutif khususnya lembaga legislatif.

PPP telah mendapat kepercayaan rakyat dengan memperoleh suara terbesar kedua pada masa orde baru dan terbesar ketiga pada masa reformasi. Namun PPP pada pemilu 2009 sampai pemilu 2019 mengalami penurunan. Meski demikian dengan pencapaian yang besar PPP tetap dipercaya oleh rakyat sebagai salah satu partai politik yang diharapkan dapat menyalurkan dan memperjuangkan aspirasinya secara optimal. Kepercayaan rakyat bisa dikarenakan program dan kinerja partai, bisa karena identitas dan jati diri partai dan kemungkinan juga karena kepemimpinan dan calon-calon legislatif yang ditampilkan oleh PPP.

Berdasarkan hasil wawancara, Syafaruddin S. Ag mengatakan bahwa "partai politik atau legislator harus terus-menerus memperhatikan, menampung dan menyalurkan aspirasi masyarakat. Membangun kepercayaan dari pemilih dan publik bukanlah pekerjaan yang hanya dan bisa dilakukan saat kampanye saja". Tanggapan tersebut sependapat dengan Butler dan Collins (2001) ia mengatakan bahwa diperlukan komunkasi politik yang dibangun berkaitan dengan marketing politik, marketing politik diperlukan karena memiliki tujuan utama yaitu bagaimana sebuah partai politik bisa mendapatkan dukungan dari publik dengan mengaplikasikan metode dan teknik yang ada di marketing. Marketing politik seharusnya tidak hanya dibangun selama periode kampanye namun lebih dari itu aktivitas haruslah permanen dan terus menerus dilakukan oleh partai politik. Karena produk yang dihasilkan oleh partai politik adalah ideologi, janji yang tertuang dalam platform partai dan program kerja. Dimana pemilih bisa mengevaluasinya dengan melihat apakah partai politik atau calon presiden konsisten dengan ideologi dan janji mereka atau tidak.

Marketing politik juga dilihat sebagai cara untuk mengurangi ketidakpastian (uncertainty) dalam hubungan antara sebuah partai politik dengan pemilih atau calon pemilih. Mereka menjelaskan tigas cara dapat dilakukan partai politik dalam mengurangi ketidakpastian hubungan yaitu information policy, certificates dan credible commitment. Contoh dari information policy yaitu 
pertemuan rutin partai, simposium, seminar dan temu kader. Dimana dalam proses ini memungkinkan adanya proses dialog, komunikasi dan transfer informasi tentang ideologi dan program antara partai dengan publiknya secara langsung. Menurut Nazli SH "mendaftar dan menjadi anggota resmi sebuah partai dan kemudian mendapatkan nomor identitas anggota adalah salah satu cara bagaimana sebuah partai politik mengurangi ketidakpastian hubungan antara partai politik dan konstituen".

Kehadiran marketing politik tidak terlepas dari polemik yang menyertainya. Hal ini tercermin dalam perdebatan alam relevan tidaknya dunia politik menggunakan cara-cara marketing dalam hubungan dengan publik (Lock, A., \& Harris, P., 1996). Sementara sisi lain tidak sedikit pihak yang melihat betapa pentingnya para politikus belajar marketing guna mengefisiensikan metode penyampaian ide, program kerja, ideologi dalam menjaga hubungan dengan public (O'cass, 1996: 45).

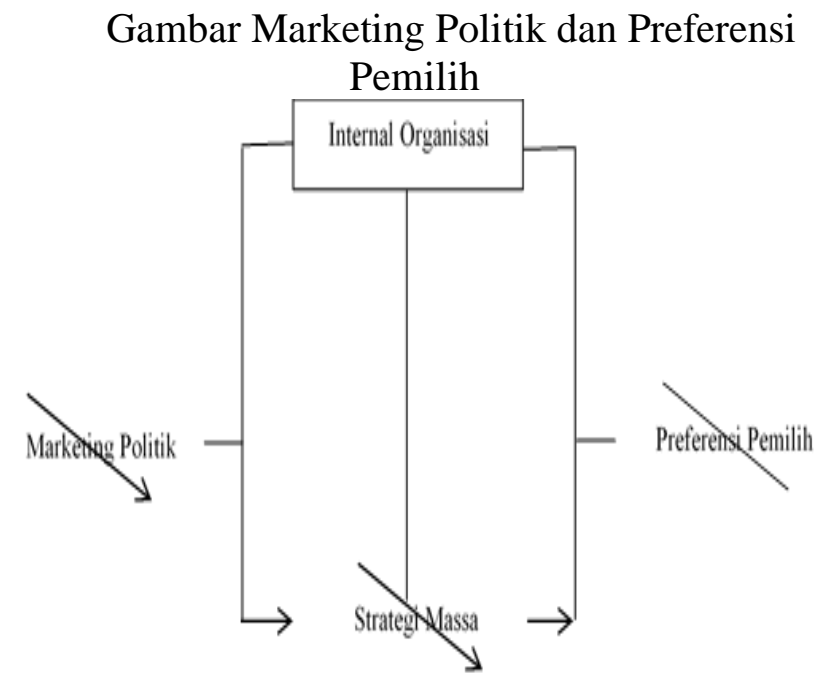

Marketing Politik Dalam Internal Organisasi

Marketing dalam internal Partai Persatuan Pembangunan (PPP) yaitu untuk dapat memahami apa yang dibutuhkan masyarakat dan aspirasi apa yang akan diperjuangan, partai politik perlu melakukan riset pasar. Penelitian yang menyangkut pasar perlu dilakukan agar bisa terus-menerus mengumpulkan informasi tentang semua hal yang akan terjadi di luar organisasi partai politik. Penelitian dilakukan untuk mengetahui perubahan yang terjadi di dalam masyarakat. Selain itu penelitian juga dilakukan guna menganalisis apa saja yang dilakukan pesaing politik, perubahan peraturan pemerintah tentang semua kebijakan yang menyangkut kehidupan berpoitik juga perlu dianalisis. Tujuan utama dari riset pasar adalah mempersiapkan organisasi politik untuk melakukan langkah-langkah adaptasi terhadap semua perubahan yang terjadi.

Berdasarkan hasil wawancana dengan Adam Malik Rambe mengatakan bahwa "Partai Persatuan Pembangunan (PPP) dalam merawat konstituen dengan cara merangkul ulama, tuan guru, guru ngaji dan tokoh Islam. Mengingat Partai Persatuan Pembangunan (PPP) sejak dulu mengedepankan nilai-nilai keIslaman".

Menurut perspektif Antonio Gramci sangat berkaitan dengan pendapat informan diatas, ia mengatakan bahwa setiap intelektual yang perannya berkaitan dengan struktur produksi dan politik masyarakat disebut dengan intelektual organik. Kiai dengan intelektual dan moral kegamaan yang dimiliki mengorganisir masyarakat (santri dan alumni) melalui ideologi yang dibangun sehingga masyarakat secara sadar dan suka rela (consensus) mengikuti apa yang dilakukan kiai (Zamahsyari, 1982: 56). 
Pengakuan masyarakat terhadap peran keunggulan intelektual dan moral kiai secara teori disebut dengan justifikasi dan legitimasi. Dalam istilah Mosca disebut sebagai political formula (formula politik) yang berarti suatu keyakinan dan kepatuhan masyarakat terhadap figur tertentu yang di dorong oleh adanya tuntunan moral terhadap kepemimpinan elit. Beranjak dari pengertian formula politik ini, maka sosol kiai bagi santri merupakan potret pemimpin religius dan kharismatik. Kiai diperlukan sebagai orang terhormat, yang dikaruniai data adikodrati dan kekuatan-kekuatan magis yang berada di atas kemampuan orang biasa.

Kenyataan ini menggambarkan bahwa posisi elite kiai dalam masyarakat patrimonial menjadi sangat penting sehingga nilai kepatuhan dan ketaatan mereka tetap terjamin. Inilah yang dalam pandangan Weber disebut dengan "legitimate domination" yaitu suatu gambaran yang menunjukkan kondisi seseorang yang mampu mendominasikan kelompok yang lebih besar. ada tiga macam bentuk "legitimate domination" yaitu traditional domination (dominasi tradisional), charismatic domination (dominasi kharismatik) dan legal rational domination (dominasi legal rasional).

Negara yang memiliki mayoritas penduduknya beragama Islam, maka sebenarnya keberadaan partai agama sangat penting dan tetap dibutuhkan. Kondisi ini seharusnya mampu dimanfaatkan secara maksimal oleh Partai Persatuan Pembangunan (PPP). As'ad Said Ali mengemukakan tiga posisi penting partai agama dalam konteks negara pancasila, partai agama secara kondusif menjaga prinsip-prinsip etis dan nilai-nilai keagamaan yang menjadi isi normative agama secara konstruktif dapat diimplementasikan, partai agama menajdi saluran penting bagi negara untuk mengalirkan dan menyerap gagasan-gagasan moralitas kegamaan masyarakat, dan partai agama dibutuhkan untuk melakukan control terhadap pelaksanaan cita-cita moral negara. Langkah pertama yang harus dilakukan Partai Persatuan Pembangunan (PPP) adalah merawat secara berkelanjutan basis-basis konstituen yang masih loyak. Dalam hal ini, kiai santri harus menajdi kekuatan utama PPP karena langkah ketua umum DPP PPP Suryadharma Ali merangkul ulama, tuan guru, guru ngaji dan tokoh Islam sudah tepat (Mulkhan, 2009).

Memang saat ini masih terlalu prematur utnuk melihat hasil dari upaya tersebut, namun paling tidak PPP sudah mengikat mereka agar tidak berpindah ke lain hati. Langkah ini cukup strategis, mengikat kiai santri sebagai basis utama PPP sering disebut dari berbagai partai politik, tidak hanya oleh partai berbasis Islam namun juga oleh partai nasionalis. Kedua adalah merebut dan memelihara kembali konstituen dan simpatisan lama yang dulu sangat loyal kepada PPP dan sekarang pindah rumah. Jalinan komunikasi dan intensitas PPP dengan kalangan kiai santri perlu terus dirawat dengan baik (Nurcholish, 1997).

Faktor Penghambat Komunikasi menurut Wursanto (2005) meringkas hambatan komunikasi terdiri dari tiga macam, yaitu: Pertama, Hambatan yang bersifat teknis Hambatan yang bersifat teknis adalah hambatan yang disebabkan oleh berbagai faktor, seperti : Kurangnya sarana dan prasarana 
yang diperlukan dalam proses komunikasi, Penguasaan teknik dan metode berkomunikasi yang tidak sesuai, Kondisi fisik yang tidak memungkinkan terjadinya proses komunikasi yang dibagi menjadi kondisi fisik manusia, kondisi fisik yang berhubungan dengan waktu atau situasi/ keadaan, dan kondisi peralatan. Kedua, Hambatan semantik Hambatan yang disebabkan kesalahan dalam menafsirkan, kesalahan dalam memberikan pengertian terhadap bahasa (kata-kata, kalimat, kode-kode) yang dipergunakan dalam proses komunikasi. Ketiga, Hambatan perilaku disebut juga hambatan kemanusiaan. Hambatan yang disebabkan berbagai bentuk sikap atau perilaku, baik dari komunikator maupun komunikan. Hambatan perilaku tampak dalam berbagai bentuk, seperti Pandangan yang sifatnya apriori, Prasangka yang didasarkan pada emosi, Suasana otoriter, Ketidakmauan untuk berubah dan Sifat yang egosentris.

$\mathrm{Hj}$ Hamidah mengatakan "setiap kali menghadiri kegiatan reses yang dilakukan legislator di daerah pemilihannya banyak pertanyaan yang dilontarkan masyarakat setempat atau konstituen dari permintaan pembuatan jalan aspal, disediakannya sarana/prasarana kesehatan seperti Puskemas, kurangnya lapangan pekejaan, dan lain sebagainya. Namun sayang semua kebutuhan masyarakat tersebut tidak bisa langsung diwujudkan".

Faktor Penghambat

1. Keterbatasan Wewenang, Ada keterbatasan yang dimiliki oleh legislator dalam mewujudkan kebutuhan masyarakat.
2. Sistem kerja kolektif kologial, Dalam mewujudkan jalan menjadi kewenangan pemerintah provinsi, tidak semata-mata langsung bisa dikerjakan. Ada proses yang harus dilakukan di dalam penentuan anggaran dan sebagainya. Jadi akan terkait dengan Komisi III yang membawahi bidang pembangunan dan infrastruktur setelah itu akan berhubungan dengan badan anggaran yang menentukan besarannya anggaran perbaikan jalan tersebut. Dari gambaran di atas terlihat dalam menentukan suatu program atau proyek perbaikan jalan dibutuhkan beberapa pihak terkait sehingga penentuan kebijakan publik menggunkan sistem kerja kolektif kologial bukan atas nama pribadi.

3. Waktu. Waktu reses seperti telah diuraikan di atas dilakukan dalam tiga masa sidang, biasanya dilakukan pada akhir bulan April, Agustus, dan Desember. Biasanya penganggaran untuk tahun berjalan telah dilakukan perencanaannya dan pembahasannya pada tahun sebelumnya oleh pihak legislatif bersama eksekutif pada tahun sebelumnya. Contohnya, permintaan masyarakat untuk perbaikan jalan merupakan hasil reses pada bulan Desember. Alhasil pembahasannya telah lewat maka rencana perbaikan jalan tersebut bisa jadi menunggu dana anggaran perubahan tahun yang akan datang sehingga perbaikannya bisa terjadi pada akhir tahun depan.

4. Kepentingan partai. Hambatan yang sering terjadi dalam proses pembahasan anggaran adalah adanya kepentingan partai yang terjadi bukan kepentingan masyarakat sehingga pembangunan di daerah tidak merata.

Disamping hambatan yang dialami, tentu banyak juga keberhasilan yang di capai oleh Partai 
Persatuan Pembangunan. Baik di skala Nasional maupun di daerah-daerah. Secara Nasional PPP memiliki sejarah dalam memperjuangkan kepentingan umat Islam melalui Undang-Undang maupun Peraturan-Peraturan Daerah. Seperti Undang-Undang Perkawinan Tahun 1974, yang dikenal dengan "Buah Perjuangan Panjang PPP”

Parlemen atau yang saat itu disebut DPR- GR kembali membahas tentang RUU perkawinan. Masa sidang yang berlangsung pada masa 19671971 itu membahas dua hal. Pertama, parlemen membahas mengenai RUU Perkawinan umat Islam yang diajukan oleh Departemen Agama pada Mei 1967. Kedua, parlemen juga membahas RUU ketentuan-ketentuan pokok perkawinan dari Departemen Kehakiman. RUU sendiri diajukan pada DPR- GR pada September 1968.

Pembahasan kedua RUU mengalami kemacetan akibat penolakan Fraksi Katolik. Dalam harian operasi April 1969. Fraksi katolik mengemukakan kedua RUU tersebut tidak sesuai dengan hakikat dan asas negara Pancasila. Macetnya masa sidang pembahasan RUU Perkawinan tak membuat Departemen Kehakiman menyerah. Pada Juli 1973, pemerintah melalui Departemen Kehakiman mengajukan kembali RUU Perkawinan yang telah dirumuskan sebelumnya. RUU Perkawinan tersebut terdiri dari 15 bab dan 73 pasal.

Pengajuan RUU perkawinan pada 1973 ternyata mendapat pertentangan dari kalangan Islam. Perlawanan datang dari Organisasi dan tokoh Islam yang lama berkecimpung dalam halhal yang menyangkut bidang agama. Penolakan tersebut disebabkan karena RUU perkawinan 1973 bertentangan dengan Pancasila dan UUD 1945.

Mengutip dari Amak FZ dalam bukunya proses Undang-Undang Perkawinan, dari komposisi kekuatan fraksi-fraksi di DPR, Fraksi PPP merupakan satu-satunya yang menentang, Alasannya karena RUU tersebut bertentangan dengan ajaran Islam.Tak lama, gelombang penolakan dan reaksi terhadap RUU perkawinan berdatangan dari berbagai komunitas. Baik itu dari masyarakat, ulama maupun pemerintah sendiri. Namun, reaksi yang menjadi sorotan datang dari Ketua Fraksi PPP KH. Yusuf Hasyim. Ia mencatat berbagai kekeliruan dalam RUU perkawinan. Bahkan, ia menganggap bertentangan dengan fikih perkawinan.Tak terkecuali dengan asas Pancasila. Bahwa, sebagai negara yang berke Tuhanan, perkawinan mestinya sesuai dengan unsure-unsur keagamaan.

Buya Hamka sejalan dengan pendapat Yusuf Hasyim. ia menolak dengan tegas draf RUU perkawinan tersebut yang dinilai bertentangan dengan ajaran Islam. Buya Hamka menilai pokok ajaran Tasyriul Islami yang dipelihara dalam syariat itu ada lima perkara. Yaitu, memelihara agama, jiwa, aka, keturunan dan harta..

Menyikapi draf RUU perkawinan inisiatif pemerintah tersebut, para ulama pada 24 Rajab $1393 \mathrm{H}$ atau 22 Agustus 1973 yang diprakarsai oleh KH Bisri Syamsuri mengadakan musyawarah bersama di Pesantren Mambaul Ma'arif, Denanyar, Lembang. Kesimpulan forum ini memutuskan usulan perubahan RUU perkawinan. Penolakan umat Islam atas RUU tersebut ternyata mendapat perhatian dari pemerintah. Lobi tingkat tinggi 
diupayakan termasuk dengan fraksi ABRI, Presiden Soeharto sendiri bertemu dengan delegasi partai atau Fraksi Persatuan Pembangunan (F-PP) yang dipimpin oleh KH Bisri Syamsuri Ketua Dewan Pimpinan Pusat (DPP-PPP) dan Masykur ( F-PP).

Akhirnya, dicapailah suatu konsensus antara kedua fraksi tersebut. Pertama, hukum Islam dalam RUU tidak akan dikurangi, Kedua, hal yang bertentangan dengan Islam dan tidak mungkin disesuaikan dalam RUU akan dihilangkan, ini berarti, draf RUU perkawinan harus diubah dengan mengacu kepada hal-hal yang telah disepakati dalam konsensus. Perjuangan tidak terhenti begitu saja. Penolakan kembali muncul, kali ini dari umat Kristen, mereka berpandangan hukum negara dan hukum agama harus bisa dipisahkan. Mohammad Daud Ali dalam "Perkawinan Campuran" menilai, penolakan ini berangkat dari doktrin mereka bahwa negara tak berhak mengatur hukum agama. Tetapi,setelah adanya kompromi dan dialog akhirnya tercapai. Hingga akhirnya setelah perjalanan panjang dan perjuangan yang alot, umat Islam bisa bernafas lega, hukum Islam telah masuk dalam UU No. 11974 tentang Perkawinan yang diundangkan pada 2 Desember 1974 dan UndangUndang tersebut berlaku sampai saat ini.

Selanjutnya pada Tahun 2013, F-PPP mengusulkan RUU Pendidikan Madrasah Diniyah untuk masuk Prolegnas (Program Legislasi Nasional). Kemudian Tahun 2015 F-PPP mengajukan Naskah Akademik dan RUU dengan judul “ RUU Lembaga Pendidikan Diniyah dan Pesantren", " ujar Jafar di Jakarta, pada tahun 2015, Komisi VIII DPR juga mengusulkan RUU
Pengelolaan Perguruan Tinggi Agama.

Pembahasan di baleg berkembang bahwa usulan ini harus mencakup semua pendidikan agama, bukan hanya khusus Pendidikan Islam. Maka semua usulan digabung menjadi " RUU Lembaga Pendidikan Keagamaan" dan masuk Prolegnas 2015-2016 nomor 109.

RUU ini dianggap sebagai langkah konkrit memperkuat Peraturan Menteri nomor 18 Tahun 2014 tentang "Satuan Pendidikan Muadalah pada Pondok Pesantren," Pada tahun 2017 juga, sambungnya, F-PPP mengadakan FGD (Forum Group Discussion) untuk mempertajam pemahaman tentang RUU Pesantren dan Pendidikan Keagamaan. Langkah ini membuahkan hasil dan draft tersebut masuk dalam daftar Prolegnas Prioritas Tahun 2017 nomor urut 43. Sehingga, lanjutnya, pada tahun 2018 di baleg diputuskan menjadi Naskah RUU Pesantren dan Pendidikan Keagamaan. Selanjutnya Partai Persatuan Pembangunan (PPP) Kota Medan melalui anggota-anggota DPRD Kota Medan yang ada di Fraksi PPP, mendesak Pemerintah Kota Medan untuk membuat Peraturan Daerah tentang Wajib Belajar Madrasah Diniyah Takmilyah Awaliyah (MDTA). dan Pemerintah Kota Medan akhirnya megeluarkan Peraturan Daerah (Perda) Kota Medan Nomor 5 Tahun 2014 tentang Madrasah Diniyah Takmiliyah Awaliyah (MDTA).

\section{SIMPULAN}

Komunikasi Politik yang dilakukan dalam menjalin hubungan dengan konstituen di kota Medan mencakup dua tahapan. Yang pertama adalah tahapan sebelum kampanye dengan melakukan analisis khalayak dengan silaturrahim 
dan sosialisasi kepada basis PPP terutama daerah yang mayoritas beragama Islam, dan tahapan kedua adalah ketika selesai kampanye dengan pendekatan tokoh-tokoh agama dari kalangan kyai dan santri, kegiatan sosial dan juga dengan marketing politk.

\section{DAFTAR PUSTAKA}

Butler, P., \& Collins, N. (1994). Political Marketing: Structure and Process. European Journal of Marketing.

Chumaidy, Chozin. (2011). Bangkitlah Partaiku: Ideologi, Strategi, dan Kepemimpinan PPP. Jakarta: Pustaka Indonesia Satu.

Dhofier, Z. (1982). Tradisi pesantren: Studi tentang pandangan hidup kyai. Lembaga Penelitian, Pendidikan, dan Penerangan Ekonomi dan Sosial.

Haris, S. (2005). Proses Pencalonan Legislatif Lokal: Pola, Kecenderungan, dan Profil Caleg. Jakarta: PT Gramedia Pustaka Utama.

Muslim, Ermalena. (2012). Modul Kaderisasi Partai Persatuan Pembangunan (PPP) Rumah Besar Umat Islam: Berkhidmat Melayani Umat. Jakarta: DPP.

Lock, A., \& Harris, P. (1996). Political marketing-vive la différence!. European Journal of marketing.

Mulkhan, A. M. (2009). Politik santri: cara menang merebut hati rakyat. Kanisius.

Nimmo, Dan. (1993). Komunikasi Politik Khalayak dan Efek. Bandung: Remaja Rosdakarya.

Nurcholish, M. (1997). Bilik-Bilik Pesantren Sebuah Potret Perjalanan. Jakarta: Paramadina.

O'cass, A. (1996). Political marketing and the marketing concept. European Journal of Marketing.

Rush, Michael, dan Althoff, Philip. (1997). Pengantar Sosiologi Politik. Jakarta: RajaGrafindo Persada.

Surbakti, Ramlan. (1999). Memahami Ilmu Politik. Jakarta: Gramedia.

Wasono, I. (1997). Etika, Komunikasi Kantor. Yogyakarta: Kanisius.

\section{Narasumber}

Wawancara dengan Rahmad Hidayat Matondang, Ketua Pimpinan Anak Cabang Kecamatan Medan Brand Ambassador Selebriti Korea Sebagai Strategi Meningkatkan Penjualan PT. Shopee Indonesia (Studi Girl Band "Gfriend" Dalam Shopee 11.11 Big Sale)
Baru di Jl. Tri Darma No. 56 Komplek Universitas Islam Sumatera Utara, pada tanggal 11 februari 2020 Pukul $10.00 \mathrm{Wib}$.

Wawancara dengan $\mathrm{Hj}$ Hamidah, Sekretaris Dewan Pimpinan Cabang PPP 2016-2021, di Jl Beringin Komplek Wartawan pada tanggal 21 Februari 2020 Pukul 10.00 Wib.

Wawancara dengan Adam Malik Rambe, Sekretaris Dewan Pinpinan Cabang Partai Persatuan Pembangunan (PPP) Medan Denai di Jl. Selam 8 No. 22 B Medan pada tanggal 24 Februari 2020 Pukul 10.00 Wib.

Wawancara dengan Syafaruddin, Ketua Pinpinan Anak Cabang Partai Persatuan Pembangunan (PPP) Kecamatan Medan Timu, Wawancara di Jl. Jemadi NO:26/237 Pulo Brayan Darat II pada tanggal 27 Februari 2020 Pukul 11.00 Wib.

Wawancara dengan Nazli SH, Selaku Ketua Pimpinan Anak Cabang Partai Persatuan Pembangunan (PPP) Kecamatan Medan Belawan, Wawancara di Lorong Dermawan No 20B pada tanggal 2 Maret 2020 Pukul 14.00 Wib.a 